\title{
Garden SERmon: \\ Being the History of a History, notes from a journal about how to keep \\ a long long project alive. \\ Or: - What I did with my \\ summer vacation.
}

I LOVE GARDENING. Transplanted to New York, I soon grew homesick for useable soil. Then I discovered a community garden where people of many races and classes grow strangely similar tomatoes. Workers share keys to one shed full of tools, and nothing ever gets stolen.

Growing food in Manhattan is a perverse joy. To eat your first tomato of the year, one you've spared not just from insects but neighborhood junkies, and probably - alas - from the deserving homeless. To taste that first popping tang of seeds and sunlight and to know that it, like you, grew despite the wailing of a thousand sirens and the pounding of construction and the stray spray of bullets as the corner bodega is robbed yet again.

On my five square feet, I soon learned to assign small jobs to local children who wander around after school, marauding, eager-like all of usto be useful, or else. If they don't like you, if you haven't given them a sense of stake in your small plot-come nightfall, they might destroy it. Since the earth has stayed the selfsame size, why do we lately feel so cornered? I send the kids for water. Our source is a fire hydrant that - stubby on the curb between Amsterdam and Columbus - considers itself a beautiful fountain. For us, it is.

I explain vegetable topics, but only when kids ask. These children believe that restaurants are where food begins and ends. One boy-squatting, pointing to carrots' green tops - doubting my promise of the orange parts hidden underground - asks with a city's pent-up longing, "Are they ready for take-out?"

But things move fast in NY, and even as we speak (as I do) our garden is being hacked away. For us, it is a tragedy. For Jackie and Angelo, my best helpers. Blades cut past soil we cultivated, blades find bedrock from which only condos will now sprout - condos into which no street kids will ever get asked. The sign says: "Guests Must Be Announced." Condos start at one hundred and eighty-five thousand for a studio. So, soilless in the city, 
I'm left to read about gardening. I fall back on this passage from an inspirational book of 1870 by one Charles Dudley Warner, My Summer in a Garden. It was recommended by the best gardener I know, a woman appropriately named Daisy. I apply this to my year off and to the novel I'm yet living with and puttering in and where I have been not unhappy for some seasons.

"The principal value of a private garden is not understood. It is not to give the possessor vegetables and fruit (that can be better and cheaper done by the market-gardener) but to teach him patience and philosophy, and the higher virtues - hopes deferred and expectations blighted, leading directly to resignation and sometimes to alienation. The garden thus becomes a moral agent, a test of character as it was in the beginning."

This pertains to projects besides books. To marriages, to children reared in the joy and pain of time, to any enterprise - enthusiastically undertaken lovingly planned-patiently sustained-steadily endured and-by the time your first tomato and/or condominum is ready - finally turned whatever color we call Ripe. And yet never quite finished. A marriage - said to end in divorce - never really stops for its participants of years. Parenthood continues even for the parents of a child who's died. And a novel rolls on "within you and without you"-a continuous Versailles and window box of how you managed, of all you might've done to make it better.

A book requires that a person-however gregarious - spend much much time alone. Somewhere, years ago, just such solitude became my own idea of luxury. I can't recall when that replaced other people's notion of fun in the sun, of fast friends and slow meals. Yeats speaks of our choice between perfection of the life or of the work. I want the work to lead me to the life, or is it vice versa? Finally, you choose whichever offers you the most, first.

What a joy: designing your whole day around writing and not just planting it as your life's herbaceous border. Since I got a grant and half an advance, since the enlightened liberal arts institution that'd just given me tenure also permitted me the privilege of taking a year off-since I left other brave souls at the helm to cover for me, and since I permitted my students to scatter to others in other offices for advice that I would and would not have given but am grateful for anyway-I found myself last May facing the terrifying joy of one free year. 
Imagine what you would do in the same circumstance. True, there's a book contract but almost everyone goes over deadline, right? You're free to risk anything or nothing, self-exploration or total indulgence. Which will it be? And who will know? If you choose to sleep till one o'clock, who'll know? Who but the grim mindful thinlipped God of John Calvin - all knowing all seeing even on the Upper West Side.

I'd laid in just enough money so I could live comfortably at my usual monkish pace but not enough to permit lengthy travel or radical new drug habits, or even radical old drug habits. Oscar Wilde warns us to beware of what we want for we might very well get it. Well, I had. For you too, it must be familiar how-once granted what you've said you craved for years - its first pure wave makes you shudder with delight and expectation and then, well, then ... just shudder. I watered my plants. A lot. William Buckley has observed that Liberals always overwater.

How to keep a long project alive? A few hard-won suggestions: When you're dead to the material, follow Keats' advice - take a long hot bath, put on a clean white shirt-his letter says it should be white and I understand this perfectly - then sit down at your desk as if you've never seen the desk or the pages on it. And start again. Or take a long walk, then start again. Or buy a plant or dog and spoil the hell out of it, then start again. During this year, not knowing they were being misted as an act of postponement or avoidance, my poor plants never had it so good. Dry times are ahead for them.

But finally, I made myself one cup too many of French Italian espresso. I hit the On switch and listened as my word-processor churned to sour neutral life. Then I muttered to myself and to a book much more than half finished, "All right, clown, put up or shut up." Being mortal, working as we were, without a net, myself and the book did some of both. Some skirting and some delivering. I see now: both were necessary. Therein hangs a tale.

1100 pages of fiction. The stamina required involves religiose devotion, blind faith and highgrade masochism and a simplifying literalness. Writing requires fifty percent talent and fifty percent character. You can have sixty percent character and forty percent talent or almost any ratio below a certain scale at either end. But the worst days can make you feel shut solely in the character-building sweatbox. 
Since all novels are about time-about people in time and how they're changed by it - or not - the element of time spent writing about time has a curious resonance. Sometimes it rings with a synchronous music-of-thespheres that is part tympany, part tinkling cymbals of delight; at others: you're up against a gothic and circular horror. With you, alone in a room, the phone unplugged (and you wondering why your friends aren't calling anyway), with you deprived of the world's gorgeous zillion inducements not to work, Time can stretch into cosmic taffy and then contract to a laser pinpoint of scary beauty. Time-the subject you pursue-is what you lose when the work is going well. A curious reward, such dropstitches. You perspire with something like stagefright and look up to find that two hours have passed in fourteen minutes. But the other also happens, a dreadful Zen clarity-unsought-it speaks the portentous arty tones of Brando in Apocalypse Now, it speaks to a working person midproject: "Here you are, alone, so alone in a room. You could be anywhere, doing anything, meeting anybody, seducing and being seduced by all that you suspect and don't yet know, but what, oh what, Zen master, have you chosen for your year of freedom? You wanted to come sit in a room with four clocks and an idea - the clocks are noisy and visible there there there and there, but the idea? The idea keeps its own hours."

I read some Saint Augustine this year. Not all of Saint Augustine-but then, time was a factor. When people ask me what I did with my sabbatical I can now say, "I read St. Augustine, why, what'd you do?" Augustine clobbered me with this line: "God did not make the world in time, $\mathrm{He}$ made the world with time."

And the same is true of a novel, and of a garden.

I tell my students: they can will the subject of a story but, a novel? no. You don't choose the subject of your novel in a vacuum any more than you pick a spouse via imagination alone. You choose from available candidates who've chosen you. Advice: if a novel comes up and proposes to you, if it suggests that you cohabit for an as-yet-unspecified number of years, the correct answer is the traditional June one - first, ask if it'll reside with you through sickness and in health till death you part and if you get a nod, then, smile, say, "I do." 
What starts a romance is rarely what sustains a marriage. My novel is called Oldest Living Confederate Widow Tells All. I consider my relation to the oldest living confederate widow my life's longest monogamous connection. What starts a young writer is not what keeps a geezer coming back for more.

You begin with the sound of one voice that goes forward into nowhere and, after years and trials enough, begins to come back with an echo, dividend. I start as a stupidly well-brought up young man, a young whitie, of middle class privilege, of country club dances, in North Carolina and that voice is naturally my own first voice and is me. It is a declarative statement and its news is my news, my life, my peeves - part talent, part character. At the first, there is more talent than character because talent is godgiven - like eyecolor - and character depends on time. There is no novelistic equivalent of Keats or of Rimbaud. There are no prodigies at character. A lyric gift has everything to do with youth and with that first great glad if possibly dark gush about what's here on earth, what's given in the garden. Many of any novel's chapters open: "The following April, Iris would learn the grim truth about Eric's infidelity." "Six weeks and an eternity later ..." Valéry, a lyric talent, swore that fiction was shabby and inferior and promised he could never write a novel since he considered emetic the central sentence of all novels. This he said ran: "The marquise went out at five o'clock."

But in time, over time, by the grace of the very time that is rushing us all toward oblivion at the same democratic clip, time that is our subjectmatter and undoing - you learn things and are altered, maybe even saddened. Certainly darkened. The voice splits as stocks do. You are subdivided and the vaguely hopeful lyric half-narcissistic thing that made you love the sound of the unique syllable "I"-brings you up against a paradox. At seventeen, I was in love with how unlike others I was. There was a clump of the select - me and two of my friends, only I wasn't so sure about one of them. Now I find, at the ripe old age of thirty-eight, that the single largest word in the English language is not "Antidisestablishmentarianism"-but that genderless and mammoth "I." How consoling to now find: I'm so much like everybody else. This is my distinction and, at its best, my work's distinction.

Only when this had happened could History impinge on my little foreground. I could not have undertaken this book six months earlier than I 
did and I still don't feel quite worthy of finishing it, though it has now turned the unmistakable red-orange of a city-ripened tomato, a streetwise one, The Big Tomato, a little tougher outside but with juice all the saddeningly sweeter for that.

My own book began preparing to pop its question in 1790 but first summoned me in 1968 in Long Beach, California of all unpromising places. I was wandering the stacks of a pretty little Carnegie Library set amongst park statues and palm trees. I was bored and eighteen. I'd been allowed to choose between six years in Federal Prison for draft evasion, or a tour of duty in the military. I picked the military. A war was on. I noticed one clump of ledgers on a dusty shelf and, having read half the library already, feeling game for anything, I opened the earliest of US census records. A first systematic headcount was taken in 1790 and-being from North Carolina, with the whole afternoon spread before me, I grabbed a volume, and since I hailed from the state's eastern seaboard, I turned to those counties, and - being eighteen - what did I look up? why, naturally, my own name. What could be more sane? If forced to read Astrological forecasts, who-among us - will not turn to his/her own birthsign?

I was in a sailor's white uniform and had been shanghaied to help with a war I'd conscientiously resisted. I felt abandoned by my Republican parents, who believed the military would make a more significant man of me and might offer me something called "the best years of my life." (My parents too are victims of their history, their war.) Being three thousand miles from home and heartsick for a comfortable if Republican house-I was surprised to find - as if listed in some North Carolina phone directory - our own peculiar family name hooked to an unmistakable ancestor from Wilmington County.

In a row of categories that reflected the 1790 patriarchy and the stillagrarian culture of my region, one entry ran:

Head of Household: Josiah Gurganus Acres owned: 960 Household's white males: 4 Household's white females: 9 Household's white servants: 3 Household's white female servants: 2 Number of livestock: 40 Male slaves: 3 Female slaves: 10.

I reread this. I remember the grain of the oak library table. I recall the mildewed volume marked 1790 , its weight, irrefutable as a Bible.

Neither my father nor grandfather-carriers of that name-had ever 
mentioned slavery as running in our family bloodstreams like a tendency toward grey-green eyes or epilepsy. That my own people had gone to Fayetteville or Charleston where such sales took place and had bought whole other families seemed to me alien and shaming. I had always prided myself as enlightened on what were then called "matters of race." My best friend on the aircraft carrier, (the only other militant reader onboard) was a black guy named Sims who called himself "Keba Montu," which meant, he told superior officers, "Brave Lion" in Swahili. "Let's see," they said, filing through the liberty cards that let you off the ship. "Radioman Second Class Brave Lion. I see a Sims here but no Lion. You're out of luck, Brave Lion pal."

Now, this. We were fond of simplifying in 1968, a moral ease much longed-for. We then said: "You're either part of the solution or you're part of the problem" - as if we all didn't have plenty of both ingredients waging constant battle in us all. But genetically, slaveowning definitely put me on the problem side. Yeah. I felt like a Rabbi discovering that his mother's maiden name was Mengele. How could I deny what was printed here-incontrovertible as Shaker design? The facts of the case were on permanent and public record, the facts - it seemed to me - of my case, of me.

We are often urged not to take things personally. A salesclerk yells at me and, shaken up by it, I tell a friend and my friend says back, "My God, you take everything so personally." Maybe that belongs on the artist's coat of arms. The agreement is: when you cease to take the world personally, you relinquish your credentials and your moral hold and your subject matter, and it's then that they issue you a gold card and they tell you that life is hard but that you should relax and then they send you on your way and you are utterly utterly lost-but it's okay because hey it's nothing personal. Just your life.

I want to keep it personal. I want the horrors of the daily New York Times to shake me up. This year, let's make a vow to each other-let's promise to take every thing personally. Let's help each other not be numb. "Deliver us from evil and lead us not into numbness." When I stop feeling embarrassment and rage, please take me out into the garden and bury me where Spot, and Muffy and the hundred family goldfish rest under crossed sticks.

But, true, not everyone would take such musty census statistics as a cen- 
tury-old moral conflict of interest. Looking over the family holdings, I understood: my only real identification was with those slaves listed just behind the livestock. (I would later learn that veterinarians often served as slaves' doctors and that, just as horses' birthdays are traditionally counted on January first, so too were the ages of a plantation's slaves.) The simple figures that stood for these people-black on a white page-gave off a clicking abacus urgency. Had I been a social scientist, I might have wondered one set of questions, had I been a politician another might have come to mind. But I looked at the number 3 and 10, slave men and women, and what I wondered, what I had to know was quite simply: their stories.

I started trying to imagine these. Since their literal tales were forever lost to me, I tried to make them up. It's nothing more profound than that; it's nothing less profound. This favor-I continue to believe-might be the best we can do for each other. To look at somebody begging on the street or somebody whizzing past you, hitchhiking, and them in an otherwise empty Rolls and to ask, "What if . .." and to send yourself as far into them as you can and to come back with some sensation that both is and is not yours and you - but which becomes you in that instant - to come back with a sensation that partakes of both parties and alchemically produces something still more complicated, more a question. To be a transitive verb, to stay not a smug statement - a stupid simple undoubted declarative sentence, but to make a perpetual question of yourself. The nimble moral yoga of "What if . . . I . . ? ?" And then to stare hard at others. Even to stare at the number 3 , the number 10.13 men and women listed under the auspices of your own overarching last name.

What I experienced within view of palm trees was not simple stupid guilt - no emotion worth writing about is that flatfooted. I've since thought how my 1968 situation prepared me to notice these bloodline facts. Nothing in my life will ever compare to the humiliation and brutalities of slavery. But, for a sassy white boy of eighteen, I was as close as I'd got. I was a stranger in a strange land. I felt a fugitive, sent by my own country on a ship to places I dreaded going, to do work nobody else wanted. My own sense of being a pawn shoved by the forces of history, an enlistee of decisions made by those whose main concern was protecting institutions for which people like me could be easily sacrificed. This surely made me sit up and notice the inherited statistics. I'm the eldest of four sons; in the 1860s, the farm would have passed to me, and the cattle, ser- 
vants, slaves. Alive in 1968, I didn't want it. I didn't want any of it. I identified not with the male forebear under whose great protective wing all others dwelt as simple numbers. I knew that I myself had become just such a hidden and expendable digit.

That really started it. I didn't know then but, through sickness and health, I'd already said yes to a subject, meaning to a question. I'd said, "I do." Or maybe, admitting to some ancestral deed, I'd said, "We did" which meant "I do."

The only thing sadder and more liberally embarrassing than being the penitent great-great-grandson of slaveowners is maybe being the impenitent one.

It always comes back to what you choose to take personally.

As a classroom exercise, I ask my fiction students to write a lovestory in the voice of someone of the opposite sex. I have found this to help complicate certain women's vision of men as only dogged and single-minded warrior-erections. I have found this especially helpful for certain male students whose characterization of women runs to all the depth and empathy implied in this humane phrase, "The big blond over there."

Students who might, early in the year, have willingly written, "The curvaceous cutie with her great throbbing alabaster globes" eventually find it harder to write: "I, the curvaceous cutie with $m y$ throbbing alabaster etceteras." Just as we read with especial care, a contract which requires our legally binding signatures-we're all reticent to second-without slow fierce attention - the holy pronoun "I."

Before history buttonholed me, before years of teaching made me notice the range and heat locked up in every voice, I wouldn't have imagined writing a seven hundred page novel in the voice of a woman - much less a woman ninety-nine years old. I wouldn't have considered this either feasible or important. It's easy to express a general sympathy with others' plight, it is something else to take the pronoun "I," peculiarly and importantly genderless in English, and to make that refer over and over again not to the "I" of a male, and one accustomed - as I am - to being listened to, one who grew up in a middling privileged world, one who has forever been encouraged not just to do his best but to expect that his best-presented honestly and honestly promoted - will lead others inevitably to respect and honor his best. To throw that over and become a person consis- 
tently overlooked - a person whose best is just a ticket for another week of the world's letting her get by, unknown, unnoticed. To retreat into the cave of some new "I"- a poorly educated woman nearly a century oldliving behind plywood partitions in a state charity ward in North Carolina. Changing places is an education. My own first person pronoun has, I think, subdivided like a simple cell, forever.

Henry James says, "A writer is someone on whom nothing is lost." And this includes losses - it's especially important not to see losses themselves as just and only losses. When I began my novel, the AIDS epidemic was a rumor that soon became a rumor about friends of friends, then true of some I knew, who soon began to die.

My age and the facts of my life place me squarely in the group most jeopardized. At such a moment, you notice. Whenever we attend the sick, our identification is our own reward. Watching anybody die is learning how it's done and-since all of us want to do things well-styles of dying go on file, set aside as help for the moment when, in a twinkling of an eye, our turn comes. But how much more you notice when the victims are in their late twenties to mid-thirties and when you are just that age and they're your closest irreplaceable friends. Astounding to hear a person who's a medical doctor and cancer researcher, himself dying of the disease, tell you in a straight cool half-bemused voice, "You know, it's quite fascinating watching oneself age forty years in six months." Your conditioned middle-class response is to intervene and deny - "oh no, you?" But the lesson of being a good companion to the dying and the living involves accepting that person's premises, even as those premises advance and shift. How odd to hear a person totally grounded in medical knowledge and, in mid July unable to walk twenty paces, busy planning a trip to England for September. You listen, you nod, you learn. You understand that a life so loves being a life alive, that it will deny rationality and reason, clinging even to the hope of planning a future - till the word "September" seems a stand-in for the long awaited millenium itself.

You volunteer to help a dying friend, you go out to get his groceries, pay his bills, pick up mail and the daily New York Times. You're headed back to his basement apartment when the newspaper tells you how our government is today cutting fifty million dollars from AIDS research while, another article explains, two million dollars are being spent to re- 
decorate the Presidential yacht. Should you claim that you forgot to buy your patient's newspaper? or maybe tear away page one? You wonder who's in charge here. Whose priorities are these? And why do we allow ourselves to be the small black numbers listed under such men's names? You wonder if you have a right to be this personally angry and if it is for others or yourself or both, yes, most likely the two, merged.

And you start to have some idea of how politicizing compassion is. All this goes into the work, you take it back into the garden. You don't use it directly, not literally and not untransfigured - but it has to go somewhere and since that's what's at the center of your life, you take it there-you do it to keep yourself sane, you do it because such callousness cries out to be transformed if not into a lesson at least into a shape, a form. Commemoration. When I started the book about a woman ninety-nine years old - my life's major foreground deaths were grandparents'. Now my casual personal daily relation to death almost parallels my ancient heroine's. And, believe me, I have used my hard won knowledge, I've used it with a vengeance.

And all of this has changed my relation to time and, therefore, to timeoff. Spare-time? Ain't no such thing. Learning this is part of what I did with my summer vacation.

Octavio Paz says, "History is a blank presence, an empty face. The poet and novelist must give this back its human features. Besides imagination, this takes moral courage." To call a particular person out of the mist is to be that person's sponsor and guardian and - finally in some strange wayto become that invented person's very dependent, her pupil.

The sense of your own narrow time drives you to wonder about all those million others whose stories have been lost like yours will be if you don't hurry, fool. You want to be accountable for them. You choose to.

My grandfather died just when I'd reached the age of first questions. A list was gathering and I went to the funeral with that list in me and hated myself for not pushing harder while I'd had him around to tell me about his parents and their farm and who'd worked the place and what he'd played at hardest as a boy and how he met the shy girl he married, how she became so forceful and why he receded into the kind of old man everybody tolerated but nobody asked anything. 
A year after the funeral, still carrying my questions, I had this dream: I was in the working district of a strange city at a sidestreet restaurant known for one food, some roll or doughnut. I walked in but only asked for coffee when I noticed an old man seated at the back. There were few other customers. He slumped in a booth and wore a rolled knitted sailor's watch-cap, he kept his big leather hands around the coffee mug for warmth, and though he didn't look like my dead grandfather, I recognized the man at once. Seeing this, he signaled that I mustn't let the others know. So I carried my coffee to his table and formally asked if I might sit. He nodded. His face was battered but merry. He seemed like some ceramic piñata stuffed with all the secrets I would finally get to ask. And I was just deciding which question to offer first when he leaned forward and-smiling - whispered in a course beautiful voice, "Everything that you suspect is so."

Quick, back to the garden.

Let's say: Each of us works a patch, each of us works alone, but it remains a community garden. You might seem to be the single person ever pulling weeds and keeping the paths clear. "Where is everybody, and what am I doing this for, and for whose benefit do I break my back to tidy up, and why aren't I appreciated?" Such are the complaints of every gardener, bugbitten at high noon. The novel and the garden and your work, my vegetable love, can use all your spine's best efforts, can use your colorsense, your knack for design in time and space. You're required to place the tall stories in back and the others down in front so they'll be visible the way a chorus must arrange its members on risers so every member, hollyhock to groundcover, can be seen singing.

Also required - and this is crucial - compost. Decay has its place-even early killing frost does. Behind (and under) each garden is the fertile rot of everyday leavings. Your potato peels, your eggshells - turned into next year's Spring.

We all think we're simply working out our own peculiar sealed-off problems but -in attending to those-we each daily master the ethical algebra that binds us to all others and the world. Partly, it comes down to our not being embarrassed by work. It is the dirty secret of modern life: Everybody just fakes leisure. They're actually working their tails off to seem so placid on the surface. 
The grand blueprint finally becomes whatever one person laboring six days a week can manage. Your own garden's size is just that and no bigger, and the rest belongs to weeds. Or to the edges of others' gardens. What you planned as another Versailles or Sissinghurst is soon just your own kitchen-plot which-seen in the right early light, covered with dew -is Versailles and Sissinghurst and then goes on from there to paradise itself.

The sins of the fathers are visited unto the second and third generations: compost. Stories.

Love and work - maybe there's some happy state between, a green spot where both are both, where we can love what we work at, where we can all work shamelessly and even harder toward what it is that we love best. This is the garden I aspire to. That will be paradise and home.

A recent book, speculating on sources of the first coded human language, suggests that we write in rows because we farmed in rows.

It's true then - "The principal value of a private garden is not understood. It is not to give the possessor vegetables and fruit (that can be better and cheaper done by the market-gardener) but to teach him patience and philosophy, and the higher virtues - hopes deferred and expectations blighted, leading directly to resignation and sometimes to alienation. The garden thus becomes a moral agent, a test of character as it was in the beginning."

Finally, this is the voice of my heroine as she speaks to the anonymous You. You come to a charity rest home with your tape recorder to find the widow of a soldier who longest outlived his Civil War. She is in bed, halfblind, gifted only with a long memory and the will that moves past will, then becomes a wiry kind of grace. Lucy speaks for me - the great grandson of slaveowners and preachers and slaveowning preachers - she speaks for all the overlooked that overseers must overlook if they're to stay the overseers - she speaks for how to survive history half-intact but mostly she speaks for herself. It remains one of fiction's illuminating technical facts that nobody who speaks for everyone in general is ever believable on the page. Only the garden tucked in a peculiar and personal first-person-singu- 
lar remains dewy as Eden and as quick with life:

"A while back you said I ought to spill my tidbits for 'history's sake.' Oh I don't need that big an excuse. I like talking. Only got one subject: what happened next. Besides, 'History,' who's she? I been breathing a while, never met her once. I just saw people waking up for work and hoping to doze those twenty minutes extra. Later, you traipse in through the backdoor loaded with names and dates and reasons. Then all that's up in front of you appears to be history.

"But, while it happens, child, history's just keeping your rooms neat and hoping company'll give you a little notice so you can tuck your extras under the bed in time. What you call history is really just the luxury of afterwards. History is how food the soldiers gobbled at eleven AM sets with them at two when the battle starts, and how one snack's heartburn changes everybody's aim.

“Honey, history ain't so historical. It's just us breaking even, just us trying to.

"Darling, you know what history is?

"History is lunch." 